\title{
PENERAPAN MODEL PEMBELAJARAN KOOPERATIF TEKNIK KANCING GEMERINCING DALAM MENINGKATKAN AKTIVITAS BELAJAR
}

\author{
Elisa Rahma Saputri \\ Prodi Pendidikan Akuntansi Universitas Negeri Yogyakarta \\ elisa.elisa91@yahoo.co.id
}

\begin{abstract}
Abstrak
Penelitian ini adalah Penelitian Tindakan Kelas (Classroom Action Research) yang bertujuan untuk meningkatkan Aktivitas Belajar Akuntansi siswa kelas XII Akuntansi 1 SMK KOPERASI Yogyakarta tahun ajaran 2013/2014 melalui Model Pembelajaran Kooperatif Teknik Kancing Gemerincing dan mengetahui respon siswa terhadap model pembelajaran. Penelitian ini dilaksanakan dalam bentuk kolaboratif yang dilaksanakan dalam dua siklus. Teknik pengumpulan data dalam penelitian ini melalui observasi, wawancara, dan dokumentasi. Analisis data yang digunakan adalah analisis kualitatif dan analisis deskriptif kuantitatif. Berdasarkan hasil penelitian disimpulkan bahwa Penerapan Model Pembelajaran Kooperatif Teknik Kancing Gemerincing dapat meningkatkan Aktivitas Belajar Akuntansi siswa kelas XII Akuntansi 1 SMK KOPERASI Yogyakarta Tahun Ajaran 2013/2014 yang dibuktikan dengan adanya peningkatan Aktivitas Belajar Akuntansi sebesar 28,25\% yaitu $53,75 \%$ pada siklus I dan meningkat menjadi $82,00 \%$ pada siklus II.
\end{abstract}

Kata kunci: model pembelajaran kooperatif teknik kancing gemerincing, aktivitas belajar akuntansi

\begin{abstract}
This is a CAR (classroom action research) that aims to improve learning activities of grade XII accounting 1 students of smk koperasi yogyakarta in year academic 2013/2014 through kancing gemerincing technique of cooperative learning method and to know students response on the learning model. The research is conducted in collaborative way through two cycles. The data collection techniques are observation, interview and documentation. Data analysis techniqu qualitative and descriptive qualitative analysis. According to the result, it can be conclude that the application of kancing gemerincing technique of cooperative learning method can improve learning activities of grade xii accounting 1 students of smk koperasi yogyakarta in year academic 2013/2014 that is proved by the improvement students learning activities as $28,25 \%$, that is from $53,75 \%$ on the first cycle and improve to $82.00 \%$ on the second cycle.
\end{abstract}

Keywords: kancing gemerincing technique of cooperative learning method, accounting learning activities

\section{PENDAHULUAN}

Potensi Sumber Daya Manusia (SDM) yang berkualitas baik merupakan suatu aset negara untuk meningkatkan perkembangan dan pertumbuhan kehidupan dunia. Pendidikan merupakan suatu proses terpenting yang harus dijaga oleh seluruh masyarakat. Pendidikan juga dapat berperan untuk mengembangkan seluruh aspek kepribadian manusia, yang 
mencakup banyak hal yakni nilai, sikap dan keterampilannya. Pendidikan juga memiliki tujuan untuk mengemban tugas untuk menghasilkan generasi muda yang berkompeten, manusia yang lebih berkebudayaan, dan manusia yang berkepribadian baik. Salah satu hal yang sangat penting dalam proses pendidikan atau pembelajaran, yaitu metode pendidikan atau metode mengajar. Metode pembelajaran merupakan cara praktis yang dipakai pendidik untuk menyampaikan materi pendidikan agar bisa efektif dan efisien diterima oleh peserta didik. Sunenti (2011) dalam penelitiannya menuliskan bahwa pembelajaran yang berkualitas dapat dilihat dalam dua aspek yakni dari aspek proses dan hasil belajar. Proses pembelajaran yang baik adalah dimana seorang guru dapat mengajak siswa aktif dalam pembelajaran yang sedang berlangsung. Aspek hasil belajar yang baik adalah dimana siswa dapat mengubah perilaku negatif menjadi positif dan menghasilkan prestasi belajar yang tinggi. Pembelajaran merupakan hal yang bersifat eksternal dan sengaja dirancang untuk mendukung terjadinya proses belajar internal dalam diri individu. Pembelajaran merupakan sebagian peristiwa atau kegiatan yang telah terstruktur dengan menggunakan teknik dan media pembelajaran. Proses pembelajaran disini bertujuan agar siswa dapat mencapai kompetensi seperti yang diharapakan (Slameto, 2010: 21). Aktivitas pembelajaran dirancang dengan tujuan untuk mencapai kompetensi tersebut. Menurut Sardiman (2011) dalam "Interaksi dan Motivasi Belajar", ada beberapa teori yang berpendapat bahwa proses belajar pada prinsipnya bertumpu pada struktur kognitif, yakni penataan fakta, konsep serta prinsip-prinsip, sehingga membentuk satu kesatuan yang memiliki makna bagi subjek didik. Teori semacam ini boleh jadi diterima, dengan satu alasan bahwa dari struktur kognitif itu dapat memenuhi perkembangan afeksi ataupun penampilan seseorang. Pembelajaran juga dapat diiringi dengan bentuk interaksi antara pendidik dengan peserta didik, peserta didik dengan peserta didik dan peserta didik dengan kelompok kerja peserta didik lainnya. Hal ini dapat terlaksana di kelas dan diselenggarakan dengan efektif dan dapat berguna untuk mencapai pengetahuan, keterampilan dan sikap yang diinginkan. Hal seperti ini tidak lepas dari adanya aktivitas dan pemahaman peserta didik di kelas yang memberikan timbal balik yang positif dan baik.

Menurut Martinis Yamin (2007) aktivitas belajar terdiri dari aktivitas fisik dan aktivitas psikis. Aktivitas fisik adalah peserta didik aktif dengan diperlihatkan 
dengan adanya gerakan badan, bekerja kelompok dengan giat, mengacungkan tangan. Aktivitas psikis adalah daya jiwa peserta didik yang berperan dalam proses pembelajaran. Hal seperti ini dapat berlangsung dengan baik jika didampingi dengan proses mendengarkan, mengamati, menyelidiki, mengingat, menguraikan dan lain sebagainya.

Peneliti mengadakan observasi di kelas XII Akuntansi 1 SMK Koperasi Yogyakarta tahun ajaran 2013/2014 pada kompetensi dasar menyusun laporan harga pokok produksi guna untuk mengetahui kondisi siswa dalam proses belajar mengajar akuntansi berlangsung. Dalam proses belajar mengajar di SMK Koperasi Yogyakarta ini masih monoton dan hanya menerapkan metode konvensional ceramah dan latihan, guru yang berperan aktif dan mendominasi kelas dalam menyampaikan materi dan siswa hanya pasif menerima materi yang disampaikan oleh gurunya. Terdapat 6 siswa dari 20 atau sekitar 30\% siswa yang mampu menunjukkan partisipasi aktif di kelas dan sisanya 14 siswa atau $70 \%$ tidak menunjukkan partisipasi aktif. Partisipasi siswa di kelas rendah ditandai dengan adannya siswa yang mengobrol sendiri dengan teman sebangkunya pada saat guru sedang memberikan penjelasan di kelas, hal ini juga akan menyebabkan aktivitas dari siswa menurun selain dengan faktor dari guru yang mengajar dengan metode konvensional juga faktor internal dari siswa itu sendiri, hal ini nampak sekali pada saat peserta didik menjawab pertanyaan yang dilontarkan oleh guru dan jawaban siswa pun kurang maksimal dijawab. Terlihat juga masih banyaknya siswa yang belum mencapai kriteria ketuntasan minimum (KKM) dalam pembelajaran akuntansi yakni 8 dari 20 siswa atau atau 40\%. Proses belajar mengajar perlu diperbaiki agar siswa dalam belajar mengajar di kelas dapat lebih fokus saat pembelajaran berlangsung. Salah satu cara untuk membenahi masalah ini dengan memperbaki strategi mengajar guru. Guru harus menyesuaikan bahan ajar dengan model-model pembelajaran yang tepat agar aktivitas siswa meningkat.

Model pembelajaran yang dapat digunakan untuk meningkatkan aktivitas siswa adalah dengan menggunakan model Pembelajaran Kooperatif. Pembelajaran Kooperatif merupakan model pembelajaran kelompok/tim kerja yaitu terdiri antara empat sampai lima siswa dan memiliki kemampuan yang berbeda (heterogen) (Wina Sanjaya, 2013: 240). Konsekuensi positif dari pembelajaran kooperatif adalah siswa diberi kesempatan untuk bebas terlibat aktif dalam kelompok masing-masing. Dalam lingkungan 
Pembelajaran Kooperatif, siswa harus menjadi partisipan yang aktif melalui kelompoknya, dapat membangun semangat pembelajaran kelompok dan saling membantu antar kelompok (Miftahul Huda, 2013: 33). Peneliti di sini melakukan penelitian dengan menerapkan model pembelajaran Kooperatif teknik Kancing Gemerincing. Kancing Gemerincing ini adalah salah satu model Pembelajaran Kooperatif merupakan pembelajaran yang menekankan pada kerjasama dalam kelompok. Serta kelebihan dari teknik Kancing Gemerincing ini adalah semua siswa terlibat sehingga keaktifan di dalam pembelajaran merata dan tidak ada yang terlalu dominan dan tidak ada pula yang terlalu pasif dalam kegiatan pembelajaran.

Model pembelajaran kooperatif teknik Kancing Gemerincing pertama kali dikembangkan oleh Spencer Kagan. Kagan mengemukakan teknik Kancing Gemerincing dengan istilah Talking Chips. Chips yang dimaksud oleh Kagan dapat berupa benda berwarna yang ukurannya kecil. Istilah Talking Chips di Indonesia kemudian lebih dikenal sebagai model pembelajaran kooperatif teknik Kancing Gemerincing (Anita Lie, 2008: 60). Keunggulan lain dari teknik ini adalah untuk mengatasi hambatan pemeratan kesempatan yang sering mewarnai kerja kelompok. Dalam banyak kelompok, sering ada anggota yang terlalu dominan dan banyak bicara. Sebaliknya di sisi lain, juga ada anggota yang cenderung hanya diam dan pasif. Dalam situasi seperti ini, pemerataan tanggung jawab dalam kelompok bisa tidak tercapai karena anggota yang pasif akan terlalu menggantungkan diri pada rekannya yang dominan.

Pelaksanakan pembelajaran dengan menggunakan Model pembelajaran kooperatif Teknik Kancing Gemerincing ini perlu adanya kerja sama kolaborasi antara guru akuntansi SMK Koperasi dengan peneliti yaitu melalui Penelitian Tindakan Kelas (PTK). PTK ini memberikan kesempatan kepada peneliti dan guru akuntansi untuk mengidentifikasi masalah-masalah yang timbul pada pembelajaran di sekolah yang selanjutnya dapat dikaji dan dicari solusi permasalahnnya. Dengan demikian proses pembelajaran akuntansi di sekolah dengan menerapkan metode melalui pembelajaran dengan Model pembelajaran kooperatif Teknik Kancing Gemerincing diharapkan dapat meningkatkan aktivitas siswa. Melalui Model pembelajaran kooperatif teknik Kancing Gemerincing peneliti berusaha untuk meningkatkan Aktivitas Belajar siswa dalam pembelajaran akuntansi di SMK Koperasi. Berdasarkan 
latar belakang di atas, maka penulis tertarik untuk mengadakan penelitian dengan judul "Penerapan Model Pembelajaran Kooperatif Teknik Kancing Gemerincing Dalam Meningkatan Aktivitas Belajar Siswa XII Akuntansi 1 SMK Koperasi Yogyakarta Tahun Ajaran 2013/2014 pada Kompetensi Dasar Menyusun Laporan Harga Pokok Produksi.

\section{METODE}

\section{Desain Penelitian}

Jenis penelitian ini merupakan penelitian tindakan kelas (classroom action research). Penelitian ini akan dilakukan dengan menggunakan dua siklus. Prosedur Penelitian Tindakan Kelas menggunakan model yang dikembangkan Kemmis dan Taggart.

\section{Subjek dan Objek Penelitian}

Subjek penelitian ini adalah seluruh siswa kelas XII Akuntansi 1 SMK KOPERASI Yogyakarta tahun ajaran 2013/2014 yang berjumlah 20 siswa, sedangkan objek penelitian ini adalah Peningkatan Aktivitas Belajar Akuntansi melalui Model Pembelajaran kooperatif teknik Kancing Gemerincing pelaksanaan pembelajaran akuntansi melalui Penerapan Model Pembelajaran Kooperatif Teknik Kancing Gemerincing dalam Peningkatan
Aktivitas Belajar Akuntansi Siswa Kelas XII Akuntansi 1 SMK Koperasi Yogyakarta Tahun Ajaran 2013/2014 pada Kompetensi Dasar Menyusun Laporan Harga Pokok Produksi.

\section{Prosedur Penelitian}

Penelitian ini direncanakan dalam dua siklus, akan tetapi apabila hasil yang diperoleh belum memenuhi indikator keberhasilan yang telah ditetapkan maka dilanjutkan untuk siklus selanjutnya. Prosedur penelitian setiap siklus terdiri dari empat tahapan, yaitu tahap perencanaan, tindakan, pengamatan dan refleksi.

Pada siklus I tahap perencanaan terdiri dari kegiatan observasi awal, menentukan tujuan pembelajaran, membuat rencana pembelajaran (RPP), membuat soal latihan dan merancang instrumen. Tahap pelaksanaan tindakan Pada tahap tindakan, guru disini melaksanakan kegiatan pembelajaran sebagaimana yang telah direncanakan diawal, yaitu kegiatan pembelajaran menggunakan model Pembelajaran Kooperatif Teknik Kancing Gemerincing. Tahap yang ketiga yaitu tahap pengamatan yang berlangsung bersamaan dengan pelaksanaan tindakan. Pada tahap ini observer mengamati aktivitas belajar akuntansi siswa selama pembelajaran 
berlangsung. Tahap terakhir adalah reflesi yang bertujuan untuk mengevaluasi hasil tindakan yang telah dilakukan yaitu dengan cara melakukan penilaian terhadap proses pembelajaran yang terjadi, masalah yang muncul, dan segala hal yang berkaitan dengan tindakan yang telah dilakukan di kelas. Setelah itu mencari solusi terhadap masalah-masalah yang mungkin timbul pada siklus I agar dapat dibuat rencana perbaikannya pada siklus II.

Prosedur pada siklus II secara garis besar sama dengan prosedur penelitian pada siklus I. Perencanaan siklus II merupakan hasil refleksi pelaksanaan siklus I. Siklus II merupakan perbaikan dari pelaksanaan siklus I, sehingga kekurangan pada siklus I tidak terulang pada siklus II.

\section{Teknik Pengumpulan Data dan Instrumen}

Teknik pengumpulan data pada penelitian ini adalah menggunakan observasi partisipatif, wawancara, catatan lapangan, dan dokumentasi. Pengumpulan data yang berhubungan dengan peningkatan Aktivitas Belajar Akuntansi dengan merapkan model pembelajaran Teknik Kancing Gemerincing dilakukan dengan observasi partisipatif dan catatan lapangan. Observer mengamati secara langsung jalannya pembelajaran untuk mendapatkan data Aktivitas Belajar Akuntansi. Observer menagamati jalannya pembelajaran dengan berpedoman pada pedoman observasi Aktivitas Belajar Akuntansi siswa yang berisi indikatorindikator Aktivitas Belajar Akuntansi.

\section{Teknik Analisis Data}

Teknik analisis yang digunakan dalam penelitian ini adalah analisis data deskriptif kuantitatif dan kualitatif. Teknik analisis data deskriptif kuantitatif digunakan untuk mengetahui skor Aktivitas Belajar Akuntansi siswa. Langkah-langkah menganalisis data secara kuantitatif adalah sebagai berikut:

a. Memberikan kriteria pemberian skor terhadap masing-masing diskriptor pada setiap aspek Aktivitas yang diamati.

b. Menjumlahkan skor untuk masingmasing aspek Aktivitas yang diamati

c. Menghitung skor Aktivitas pada setiap aspek yang diamati dengan rumus:

$\%=\frac{\text { Skor hasil Aktivitas Belajar siswa }}{\text { Skor Maksimum }} \times 100 \%$

(Sugiyono, 2009: 144)

Teknik analisis data kualitatif terdiri dari dua langkah. Pertama, Penyajian data: penyajian data dalam bentuk diagram, tabel, grafik, pie chart, 
dan sejenisnya. Dari penyajian ini dapat memudahkan pembaca dalam memahami dan menafsirkan data yang diperoleh dengan benar dan mengetahui rencana kerja yang dilakukan peneliti selanjutnya. Kedua, penarikan kesimpulan: langkah terakhir ini merupakan suatu kesimpulan yang dapat ditarik oleh peneliti dari masalah dan rumusan masalah yang disajikan. Verifikasi ini, tidak mutlak harus sesuai dengan apa yang diharapkan, karena hasil verifikasi ini tergantung dari data lapangan yang diperoleh dan verifikasi diharapkan merupakan sebuah temuan baru yang belum pernah ada.

\section{Indikator Keberhasilan}

Kriteria keberhasilan tindakan adalah apabila setelah penerapan Model Pembelajaran Teknik Kancing Gemerincing, terjadi peningkatan Aktivitas Belajar Akuntansi. Keberhasilan tindakan aktivitas belajar terlihat apabila terjadi peningkatan pada aspek aktivitas. Pembelajaran dikatakan berhasil dan berkualitas apabila seluruhnya atau setidak-tidaknya minimal $(75 \%)$ peserta didik terlibat secara aktif, baik fisik, mental maupun sosial dalam proses pembelajaran, di samping menunjukkan kegairahan belajar yang tinggi, semangat belajar yang besar, dan rasa percaya diri sendiri (Mulyasa, 2010: 218).

\section{HASIL DAN PEMBAHASAN}

Hasil penelitian yang diperoleh dari siklus I belum mencapai kriteria keberhasilan tindakan. Rata-rata Aktivitas Belajar Akuntansi siswa pada siklus I hanya mencapai 53,75\%. Pada siklus I belum ada indikator yang memenuhi kriteria keberhasilan, karena siswa masih belum begitu jelas dengan teknik Kancing Gemerincing ini. Selain itu pelaksanaan pembelajaran pada siklus I juga belum sistematis dan terorganisir dengan baik. Hal tersebut disebabkan oleh beberapa hal seperti siswa belum paham dengan model pembelajaran baru sehingga sering terjadi salah pemahaman antara guru, siswa dan peneliti sehingga Aktivitas Belajar Akuntansi siswa pada siklus I belum tercapai secara optimal.

Berdasarkan hasil tersebut, maka pada siklus II perlu dilakukan perbaikan agar Aktivitas Belajar Akuntansi siswa kelas XII Akuntansi 1 dapat mencapai kriteria yang telah ditentukan oleh peneliti. Perbaikan yang dilakukan pada siklus II yaitu pembelajaran dirancang dengan lebih disiplin dan interupsi yang jelas, soal diskusi yang lebih beragam dengan tingkat kesulitan yang berbeda dengan siklus I sehingga proses diskusi belajar akan lebih terlihat semangat. Terbukti adanya peningkatan sebesar $28,25 \%$ yaitu menjadi $82,00 \%$ pada siklus II dan semua indikator 
telah mencapai lebih dari 75\%. Untuk lebih jelasnya, berikut ini disajikan data perbandingan skor Aktivitas Belajar Akuntansi siklus I dan siklus II.

Tabel 1. Perbandingan Peningkatan Aktivitas Belajar Akuntansi Siswa

\begin{tabular}{cccc}
\hline & \multicolumn{2}{c}{ Skor } & Pening- \\
No $\quad$ Indikator & Siklus I Siklus II & katan \\
$(\%)$ & $(\%)$ & $(\%)$
\end{tabular}

Memperha-

1 tikan $53,75 \quad 78,75 \quad 25,00$

penjelasan guru

2 Siswa mengajukan $52,50 \quad 80,00 \quad 27,50$ pertanyaan

Siswa bekerjasama dengan $55,00 \quad 88,75 \quad 33,75$ teman satu kelompok

\section{Bertanggung} jawab atas tugas

5 Mendiskusikan masalah $57,50 \quad 81,25 \quad 23,75$ yang timbul

Partisipasi

6 siswa dalam menjawab pertanyaan

Siswa

7 mengerjakan soal atau pertanyaan $56,25 \quad 86,25 \quad 30,00$

\section{Siswa}

8 melaporkan $\quad 52,50 \quad 83,75 \quad 31,25$ jawabannya

\section{Siswa}

9 menyimpulk $\quad 50,00 \quad 77,50 \quad 27,50$ an hasil diskusi.
$10 \begin{aligned} & \text { Siswa berani } \\ & \text { memberikan }\end{aligned} \quad 47,50 \quad 76,25 \quad 28,75$ tanggapan

Rata-rata

Aktivitas

$53,75 \quad 82,00$

28,25

Belajar

Akuntansi

Perbandingan skor Aktivitas Belajar Akuntansi per indikator untuk siklus I dan siklus II dapat disajikan pada grafik berikut ini:

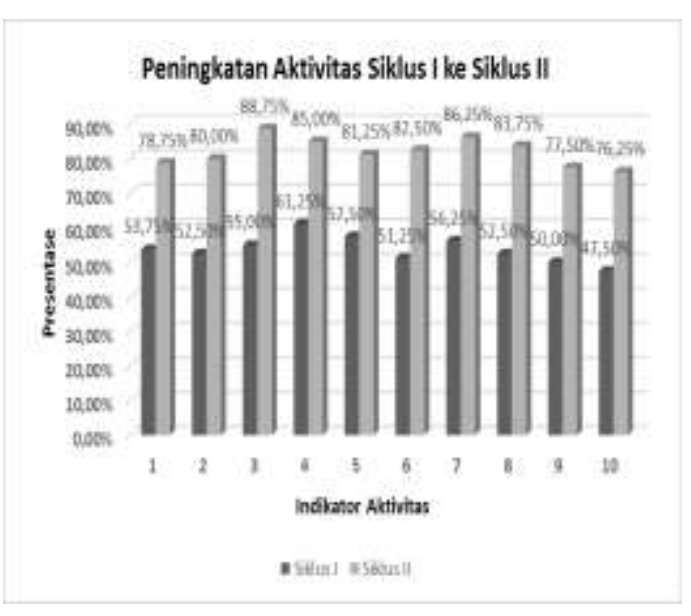

Gambar 1. Grafik Data Observasi

Aktivitas Belajar Akuntansi Siklus I dan II

Berdasarkan pembahasan tiap indikator Aktivitas Belajar Akuntansi diatas secara garis besar diperoleh peningkatan skor pada setiap indikator 
yang telah ditentukan. Model pembelajaran yang sesuai akan mendukung peningkatan aktivitas siswa tersebut. Seperti yang diungkapkan oleh Agus Suprijono (2012: 54) peserta didik bertanggungjawab atas mereka sendiri dan menemukan informasi untuk menjawab pertanyaan yang diajukan kepada mereka. guru bertindak sebagai fasilitator, guru memberikan dukungan tetapi tidak mengarahkan kelompok ke arah hasil yang sudah disiapkan sebelumnya. Bentukbentuk assesment oleh sesama peserta didik digunakan untuk melihat hasil prosesnya. Hal ini sejalan dengan model pembelajaran dan teknik yang diterapkan yaitu dengan model pembelajaran Kancing Gemerincing. Siswa diberi kesempatan untuk mengeksplor pengetahuan sendiri dan diarahkan oleh guru.

Berdasarkan hasil wawancara yang telah dilakukan pada siswa, diketahui bahwa rata-rata siswa kelas XII Akuntansi 1 SMK Koperasi Yogyakarta tahun ajaran 2013/2014 menunjukkan respon yang positif terhadap Penerapan Model Pembelajaran Kooperatif Teknik Kancing Gemerincing. Siswa merasa senang dengan adanya penerapan model pembelajaran tersebut karena dapat menciptakan adanya suasana pembelajaran yang baru dan berbeda dalam rutinitas belajar mengajar yang berlangsung, selain itu siswa juga menjadi tidak cepat bosan selama mengikuti pembelajaran karena melalui model pembelajaran tersebut siswa dikondisikan untuk aktif Siswa tidak hanya duduk dan diam mendengarkan materi dari guru saja melainkan siswa juga melakukan kerja sama dan diskusi dengan kelompoknya sehingga lebih tercipta interaksi, komunikasi dan kerjasama, baik antar siswa maupun antara siswa dengan guru.

\section{SIMPULAN DAN SARAN}

\section{Simpulan}

Berdasarkan hasil penelitian dan pembahasan pada bab sebelumnya, maka dapat disimpulkan bahwa penerapan Model Pembelajaran Kooperatif Teknik kancing gemerincing (Talking chips) dapat Meningkatkan aktivitas Belajar Akuntansi Siswa kelas XII Akuntansi 1 SMK Koperasi Yogyakarta Tahun Ajaran 2013/2014. Hal ini dibuktikan dengan adanya peningkatan rata-rata skor aktivitas belajar akuntansi siswa yang diperoleh melalui observasi dengan menggunakan lembar observasi yang memuat sepuluh aspek Aktivitas Belajar Akuntansi siswa yaitu 53,75\% pada siklus I dan meningkat sebesar $28,75 \%$ sehingga menjadi $82,00 \%$ pada siklus II. Selain itu setiap indikator Aktivitas Belajar Akuntansi juga mengalami peningkatan. 
Berdasarkan hasil wawancara yang telah dilakukan pada siswa, rata-rata siswa kelas XII Akuntansi 1 SMK Koperasi Yogyakarta tahun ajaran 2013/2014 menunjukkan respon yang positif terhadap Penerapan Model Pembelajaran Kooperatif Teknik Kancing Gemerincing (Talking Chiphs). Siswa merasa senang dengan adanya penerapan model pembelajaran tersebut karena dapat menciptakan adanya suasana pembelajaran yang baru dan berbeda dalam rutinitas belajar siswa. Selain itu, siswa juga menjadi tidak cepat bosan selama mengikuti pembelajaran karena melalui model pembelajaran tersebut siswa dikondisikan untuk aktif dilihat secara keseluruhan maupun dilihat dari setiap indikator baik pada siklus I maupun siklus II.

\section{Saran}

Siswa kelas XII Akuntansi 1 SMK Koperasi Yogyakarta menunjukkan tanggapan yang baik setelah dilaksanakan Model Pembelajaran Kooperatif. Melihat hal tersebut peneliti menyarankan kepada guru untuk menggunakan Model Pembelajaran Kooperatif Teknik Kancing Gemerincing dikemudian hari sebagai salah satu alternatif pembelajaran Akuntansi selanjutnya. Dapat mempergunakan hasil penelitian ini sebagai kajian untuk diadakannya penelitian lebih lanjut tentang Implementasi Pembelajaran Kooperatif Teknik Kancing Gemerincing untuk meningkatkan kualitas pembelajaran. Diharapkan bagi peneliti lain harus memperjelas lagi Skala penilaian atau dibuat lebih operasional mengenai indikator yang akan diteliti. Hal seperti ini dapat mengurangi kebingungan observer dalam memberikan penilaian.

\section{DAFTAR PUSTAKA}

Agus Suprijono. (2012). Coopertaive Learning Teori dan Aplikasi PAIKEM.

Anita Lie. (2008). Cooperative Learning: Mempraktikkan Cooperative Learning di Ruang-Ruang Kelas. Jakarta: Grasindo.

Miftahul Huda. (2013). Cooperative learning. Yogyakarta: Pustaka Pelajar.

Mulyasa, E. (2011). Praktik Penelitian Tindakan Kelas. Bandung: Remaja Rosdakarya.
Rusman. (2011). Model-Model Pembelajaran Mengembangkan Profesionalisme Guru. Jakarta: Rajawali Pers.

Sardiman.A.M. (2011). Interaksi \& Motivasi Belajar Mengajar. Jakarta: Rajawali Pers.

Slameto. (2010). Belajar dan Faktorfaktor yang Mempengaruhinya. Jakarta: Rineka Cipta. 
Jurnal Pendidikan Akuntansi Indonesia, Vol. XII, No.1, Tahun 2014 Elisa Rahma Saputri

$25-35$

Sugiyono. (2011). Metode Penelitian

Kuantitatif Kualitatif dan $R \& D$.

Bandung: Alfabeta.

Wina Sanjaya. (2013). Penelitian

Pendidikan. Jakarta: Kencana

Prenada Media Group. 